\title{
Innovations in Trade Financing Process of Commercial Bank
}

\author{
Yijun Yuan, Xiaowei Dong \& Xiaoqing Lv \\ Department of Economics, Dalian University of Technology \\ Dalian 116024, China \\ Tel: 86-411-8470-7830Ｅ-mail: Lvxiaochong1111@yahoo.com.cn
}

\begin{abstract}
From the point of view of bank process reengineering theory, the paper focuses its discussion on definition and features of international trade financing based on the principles and requirements of financial innovation. Through the clarification for international trade financing process and comparison for ways of international trade financing under traditional trade settlement methods, trade financing process innovation has been fulfilled.
\end{abstract}

Keywords: Bank Reengineering, Trade Financing, Process Innovation

\section{Introduction}

International trade financing refers to credit support related to trade settlement in import and export, which commercial banks provide to importers and exporters. The constant development of international trade requires commercial banks to make substantial innovation for trade financing process. Therefore, based on the theory of bank reengineering, we studies and takes advantage of existing trade financing methods to fulfill trade financing process innovation, which becomes one of the most important channels to adapt to development of financial market and improve competitive ability for commercial banks.

At present, rapid growth of international trade brings huge market opportunity to the development of international trade finance. There are enormous opportunities for the financier in developing internal Chinese commodity sources. The potential for the trade financier is huge, not only in the field of commodity, but also the field of service.

Existing researches on trade financing innovation at home and abroad almost lie in the fields of financial product innovation; in contrast, trade financing process innovation is seldom concerned except in some researches on bank process reengineering. Thereby, it is very meaningful to study international trade financing process innovation based on the theory of bank process reengineering.

\section{Framework of Trade Financing Process Innovation: in Perception of Bank Reengineering}

As the process of finance liberalization, informationization and securitization, the theory of bank reengineering has developed as well since the second half of the 20th century. The rising of bank reengineering urged the theoretical development of finance innovation, and became a central issue, which was paid much attention by scholars home and abroad. Nowadays, the process design of commercial bank has not been suitable for the requirement of rapid development of finance industry, so it becomes an important channel to innovate trade finance through innovating trade financing process, combining the finance innovation with theory of bank reengineering.

The phrase bank reengineering came from the phrase enterprise reengineering. Through a long period exploration and practice, the theory of bank reengineering is summarized by international commercial bank, used to immerging creative reform for organization, product and process of bank. Bank process reengineering is the core content of bank reengineering. Its purpose is reengineering scattered task of every functional department and outsourcing non-value-added service to improve the operating efficiency, according customer category and operating process of customer value creation.

Applying effectiveness priority principle of bank process reengineering to trade financing process innovation is making operating process accepted by the market, which is designed for trade financing product. It is an efficiency issue of process reengineering. It must enable reengineered process to be suitable for either product nature or requirement of different customers.

In the meanwhile of improving efficiency, cost reduction is another requirement of trade financing innovation. The cost reduction oriented function virtual principle assimilates resources out of the organization into the organization to 
complete organizational function. This principle requires commercial bank to reserve critical and dominant services in the process of trade financing and outsourcing non-value-added or less-value-added parts to those professional agencies. Through this kind of mutual supplement, the value created in trade financing process is increased.

Resource integration principle is a theory of combine of labor in bank reengineering theory, on the contrary of theory of labor division. Based on utilization of information technology, this principle takes trade financing process restructure as breakthrough to assemble dilatory process reasonably.

\section{Carding of Trade Financing Process}

Prior to innovating trade financing process, we should be familiar with process of these services. Based on process carding, trade financing process innovation is completed. The text probes innovative methods of trade financing process, and its application and development in practice.

\subsection{Carding of Trade Financing Process with Three Participants Involved}

The participants, involved in this kind of trade financing process, include importer (exporter), importer's bank and exporter's bank. The representing services consist of Import Bill Advance, Forfaiting and so on.

The flow program is showed as Figure 1.

Forfeiting is a typical representative of this kind of trade financing services. Therefore, taking Forfaiting as an example, the text will introduce the specific process of this kind of trade financing service, which consists of six steps.

(1) Fix the purchasing bank. Firstly, exporter will make an inquiry to banks, and then fix a bank as the purchaser.

(2) Present the documents. The exporter will present materials to the purchaser, such as importer's details, goods and amount of money, in written form. After bank checking the documents, the exporter and the importer would sign the trade contract, in which Forfaiting is the method of trade financing.

(3) Acceptance of the importer. After getting acceptance of exporter's bank, the exporter would issue a time draft to the importer.

(4) Post the receipts. After dispatching the goods, the exporter will send all the cargo documents to the importer through banking system; and the importer will send accepted time draft to the exporter.

(5) Purchase the receivables. After getting the accepted time draft, the exporter will discount the draft to the forfeiter in a non-recourse way with agreed discount rate.

(6) Sign the Forfating agreement. After receiving the documents presented by the exporter, the purchasing bank will sign the Forfaiting agreement, and pay cash to the exporter.

\subsection{Carding of Trade Financing Process with Four Participants Involved}

The participants, involved in this kind of trade financing process, include importer, exporter, importer's bank and exporter's bank. The representing services consist of Export Discount, Packing Loan, Export Bill Purchase and so on.

The flow program is showed as Figure 2.

Figure 2 Flow Program with Four Participants Involved

Export Bill Purchase is a developed trade financing service. Therefore, take it as an example to introduce the specific process of this kind of trade financing service, which consists of five steps.

(1) Submit an application. The exporter submits an application for Export Bill Purchase to correspondent bank.

(2) Submit relative materials. The exporter provides the correspondent bank with trade contract, L/C, all receipts accompanied with $\mathrm{L} / \mathrm{C}$ and so on.

(3) Examine the materials and pay the cash. After all the materials are verified, an agreement will be signed, and then the bank will pay cash to the exporter.

(4) Present the receipts. The exporter's bank presents all the receipt accompanied with $\mathrm{L} / \mathrm{C}$ to the importer's bank (usually opening bank). After all the receipt are verified, the importer's bank will present for payment to the importer.

(5) Withdraw the money. When $\mathrm{L} / \mathrm{C}$ expires, the importer will pay the number of money listed on the $\mathrm{L} / \mathrm{C}$ to the opening bank, and then the opening bank will cover draft the money to the exporter's bank.

\subsection{Carding of Trade Financing Process with Five Participants Involved}

The participants, involved in this kind of trade financing process, include importer, exporter, importer's bank, exporter's bank and shipping company (or insurance company). The representing services consist of Shipping Guarantee, Credit Insurance under the Trade Financing and so on.

The flow program is showed as follow. 
For the purpose of avoiding risks, the insurance part is more and more introduced in trade financing service. Take Credit Insurance under the Trade Financing as an example to introduce the specific process of this kind of trade financing service, which consists of six steps.

(1) Insure export credit insurance. The exporter insures short-term export credit insurance for the trade settlement. After getting credit line, submit the financing application to the bank, which has business contact with the exporter.

(2) Fill in tripartite agreement. The exporter and the bank fill in Indemnity Transfer Agreement of triplicate. Afterward, the exporter takes one of them to negotiate with the bank. (Figure 3)

Figure 3 Flow Program with Five Participants Involved

(3) Submit the receipts. When the exporter is negotiating with the bank, he should submit the financing application and all the relative receipts.

(4) Check the receipts and pay the cash. After all the materials are verified, the bank will sign the agreement with the exporter and pay the cash to the exporter.

(5) Present the receipts. The exporter's bank presents all the receipts to the importer's bank. After all the receipts are verified, the importer's bank will present to payment to the importer.

(6) Withdraw the money. When L/C expires, if the importer does not pay the money back to his bank, the insurance company will pay the indemnity to the bank.

\section{Trade Financing Process Innovation}

Based on the carding of trade financing process with different participants above, the paper will carry out process innovation in three aspects as follow, using the principles of bank reengineering as guidance.

\subsection{Effectiveness Priority Principle and Carding of Trade Financing Process}

No matter which kind of trade financing services, there is something identical. Selecting the identical or similar operating process in trade financing process, and then identify these parts with each other. In this way, the similar parts of every kind of trade financing services are not need to be charged by specialized person respectively, but by a single clerk or a service team. This is the main thought of lateral spreading of trade financing process. This kind of lateral spreading does not only simplify the processing steps of trade financing services, but also reduce the cost and improve the efficiency.

These three kinds of trade financing services mentioned above have the same steps, such as submitting the application and presenting the receipts. Although different kinds of trade financing services need to submit different application and receipts, but what these function departments need to do is receiving all kinds of applications and receipts. After carrying out lateral spreading, what the service team need to do is just clarifying and checking different applications and receipts, and then sending them to different function department to do further processing.

It is very important to standardize trade financing process. However, because of the service feature of trade financing, the customers and environment are of variety. Therefore, the design for business process should focus on requirement of flexibility. Through clarifying different kinds of customers and conditions of environment, trade financing process is designed. Based on the standardization, use the flexible principle to handle complicated situation. This is the main thought of flexible design of trade financing process.

For example, according the credit line of single trade financing service, commercial bank could establish different approving mechanism. Bank could carry out sub-management, and set up different approving standard for every credit line, even use the automatic approval mechanism.

\subsection{Function Virtual Principle and simplification of trade financing process}

There existing some redundant or non-value-added steps. Only if they are removed from trade financing process, the value creation advantage could be displayed further. Through selection to specific trade financing steps, remove those steps which can not reduce the cost by the way of specialization, and keep those critical steps which can increase value significantly. This is the main thought of internal simplification of trade financing process. In this way, commercial banks overcome the defect of large and all-inclusive to own a path of value creation advantage.

All kinds trade financing services mentioned above exist step of checking receipts. In practice, customer managers do preliminary check and then regional data processing center do further and thorough examination. In fact, customer managers' checking could be removed, because the substantial mistakes could only be found by those professional clerks from regional data processing center. Therefore, this kind of internal simplification is the way of getting value-added advantage.

External expansion takes internal simplification as the foundation, that is to say, the purpose of internal simplification is for conducting external expansion efficiently. As the weakening of some trade financing steps inside the commercial 
bank, the bank should search the resources outside, and assimilate them inside. This is the main thought of external expansion of trade financing process. The purpose of this kind of innovation method is to reduce the cost and enhance competitiveness of commercial banks.

For now, most of risk control of trade financing is feed forward control, that is to say, commercial banks only control risks that happen before financing funds' deliver. There is no such a risk control mechanism, which identifies and control risks during the whole process of trade financing. However, this would increase managing cost remarkably. Therefore, commercial banks could utilize resources outside to reduce the cost, as well as get professional services.

\subsection{Resource Integration Principle and Integration of Trade Financing Process}

Trade financing belongs to financial services. Financial services should base on resources integration and fulfill the organic combination of technical resources, organizational resources and capital resources to form core competitive strength. The purpose of resource integration is to get more effective financial services.

The application of resource integration in trade financing innovation should be multi-level and omnibearing. Generally, resource integration should carry out in four levels; those are personal level, team level, single enterprise level and virtual enterprise level. Resource integration of trade financing mainly focuses in the first two fields.

Only if resources are integrated in the whole chain of trade financing, commercial banks could improve efficiency and embody the principle of maximizing customers' value. The main thought of customers' value exemplification of trade financing is taking the customer as the core process design, not the banks themselves in a traditional way.

At present, the steps, needing to contact with customers, are scattered in different functional department, which makes customers feel difficult in this procedure. However, if taking the customers as the core of process innovation, commercial banks should integrate all those customers-contact links together and provide a sequence services to the customers. In the meanwhile of increasing customers' utility, the efficiency of commercial banks is improved.

\section{Conclusion}

Taking the theory of bank process reengineering as the analyzing framework, the text cards the general process with different participants. Combining the principles of bank reengineering, commercial bank should carry out the simplification, expansion and integration for trade financing process. Trade financing process innovation would fulfill the purpose of customers-centralized and market-oriented, and embody the value-added advantage.

\section{References}

Andrew M. Moravcsik. (1989). Disciplining Trade Finance: The OECD Export Credit Arrangement. International Organization. Vol. 43, No. 1, Oct., pp. 173-205.

C. Bram Cadsby \& Elizabeth Maynes. ( 1998). Laboratory Experiments in Corporate and Investment Finance: A Survey.Managerial and Decision Economics.Vol.: 19, No. 4/5, Jun. - Aug., pp. 277-298.

Charles Tennant \& Yi-Chieh Wu. (2005). The application of business process reengineering in the UK.The TQM Magazine. Volume: 17, Issue: 6, June, pp: 537 - 545.

Helen E. S. New Institutional Architecture Evolving Structures for Managing Trade, Financial, and Security Relations. The Political Economy of the Asia Pacific.

Jonathan Eaton \& Samuel Kortum. (2002). Technology, Geography and Trade.Econometrica, Vol.: 70, issue: 5, Sep., pp. 1741-1779.

Laurence Weiss. (1980). A Model of International Trade and Finance. Vol.: 95, issue: 2, Sep., pp. 277-292.

Mike Burkart \& Tore Ellingsen. (2004). In-Kind Finance: A Theory of Trade Credit. Vol. 94, No. 3, Jun., pp. 569-590.

Namchul Shin \& Donald F. (2002). Jemella.Business process reengineering and performance improvement: The case of Chase Manhattan Bank. Business Process Management Journal.Volume: 8, Issue: 4, April, pp: 351 - 363.

Olaf Weber \& René Beeler. (1999). Incorporating sustainability aspects in structured trade and commodity finance.Journal of Applied Accounting Research. Volume: 5 Issue: 1, Jan., pp: 97 - 111.

Paul Reding \& Jean-Marie Viaene. (1995). Capital controls and international trade finance in a dual exchange rate regime: The Belgian experience post-mortem. Review of World Economics. Vol. 131, No. 1, March. 


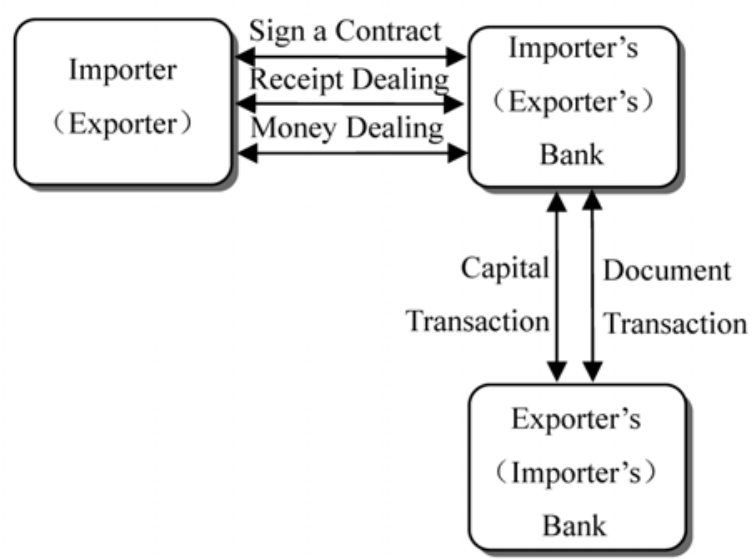

Figure 1. Flow Program with Three Participants Involved

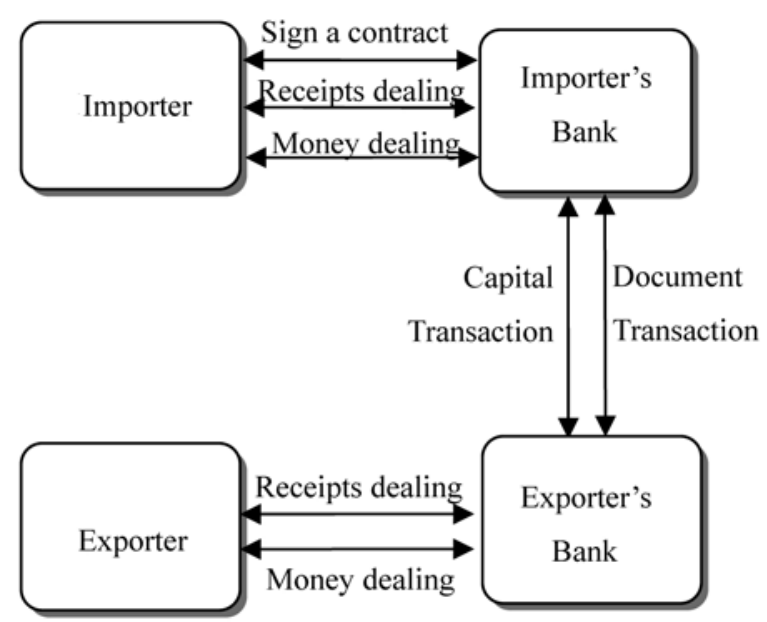

Figure 2. Flow Program with Four Participants Involved

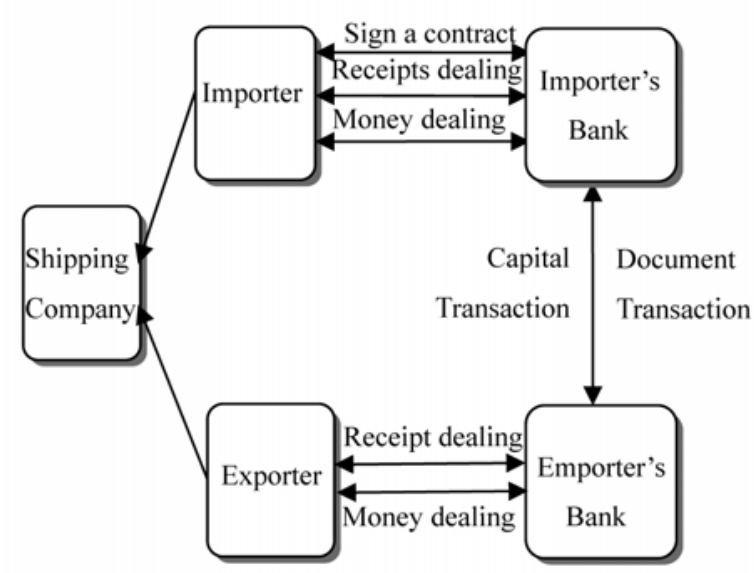

Figure 3. Flow Program with Five Participants Involved 